\title{
Role Performance of Krishak Mitra
}

\author{
Veerpal Maina, Kamini Bisht*, S.P. Singh and Sheela Raghuwanshi \\ Department of Extension Education, JNKVV College of Agriculture, Tikamgarh, M.P., India \\ *Corresponding author
}

\section{A B S T R A C T}

\section{Keywords}

Krishak Mitra, Agriculture extension services, Tikamgarh

Article Info

Accepted: 07 December 2018 Available Online: 10 January 2019
The technological development in the field of agriculture has broadened the need for farmers. This calls for the use of local leaders who can act as linkers between farmers, extension personnel and exercise influencing in bringing about accelerated adoption of technologies. The Krishak Mitra is also one type of leaders/opinion leaders and they communicate the recent technologies to farmers and also bring the problems of farmers to concerned authorities. The effectiveness of Krishak Mitra in terms of their ability to perform the roles entrusted to them depends upon their performance as well as the satisfaction from their role as Krishak Mitra, besides that it also depends upon their profile characteristics affecting them. Keeping this in mind, the present study on Role performance of Krishak Mitra was conducted in Tikamgarh district of Madhya Pradesh. The findings of the study revealed that majority of Krishak Mitra were in medium category of role performance followed by high and low. As far as constraints faced by Krishak Mitra in performing their roles is concerned, low payment was one of the major constraint responded by majority of the Krishak Mitra.

\section{Introduction}

Agriculture extension services were established in India to provide rural clientele with practical and useful information relevant to solving their agricultural problems. Over the years, India has made progress in the area of agricultural development. Soon after the T \& V programme there were no VLWs at the village level for assisting the farmers in solving their problems and transfer of improved technologies to the farmers. Involvement of farmers can be achieved at the village level through farmer's interest group (FIGs), at block level as a member of farmer's advisory committee (FAC) and at district level as the member of Agriculture Technology Management Agency (ATMA) governing board.

The concept of ATMA envisages paradigm shift from "top down" to "bottom up" in the planning and implementation of agriculture development programmes. There is a need of a person who acts as extension worker in a village, so a farmer's friend from the same village is selected under ATMA schemes for this purpose through the Gram Sabha of Gram Panchayat and locally known as "Krishak Mitras". 
It is generally accepted that the effectiveness of any set of people is largely dependent on the quality of its leadership - effective leader behaviour facilitates the attainment of the follower's desires, which then results in effective performance (Maritz, 1995). The effectiveness of extension services is also highly dependent on the ability of extension workers who are competent as the whole extension process is dependent on them to transfer information from extension organizations to the clients. The important position of this crucial change agent in the extension approach makes it necessary to understand his/her all dimensions. Previous studies have identified various competencies needed by extension workers in technical areas and human development areas as well. It was found that these competencies should be possessed by extension workers in order to effectively perform their role (Gibson and Hillison, 1994; Cooper and Graham, 2001; Miller and Cox, 2006). In view of recent advancement in the agricultural technologies and more and more involvement of Krishak Mitra in agriculture, the role of Krishak Mitra is not just to educate the Krishak Mitra regarding agriculture technologies but they have to pay equal attention towards dissemination of agro-based technologies for the socio-economic upliftment of the rural families. As a result, it was found that there is a necessity to investigate performance and factors that might contribute to the understanding of Krishak Mitras' performance. In view of this, the present study entitled "Role performance of Krishak Mitra was conducted.

\section{Materials and Methods}

The present investigation was carried out in Tikamgarh district of Madhya Pradesh. Tikamgarh district comprises of six blocks i.e. Tikamgarh, Niwari, Prithvipur, Baldeogarh, Palera, and Jatara. All six blocks of
Tikamgarh district were selected for the study purpose. List of the Krishak Mitra was obtained from the Department of Farmers Welfare and Agriculture Development. From each blocks, 20 Krishak Mitra were selected randomly thus, total 120 respondents were selected for the present investigation.

\section{Results and Discussion}

\section{Profile of Krishak Mitra}

Majority of the Krishak Mitra (67.50\%) belonged to middle age group followed by young age $(18.33 \%)$ and old age $(14.17 \%)$. The results might be due to that the young farmers might have been engaged in other developmental activities, whereas the selection committee of Krishak Mitra might have considered middle aged farmers as Krishak Mitra due to maturity and experience of Krishak Mitra. The findings of the present study are in line with the findings of Rao (2002), Roy (2003).

In case of educational qualification, maximum number of respondents $(42.50 \%)$ were found to be educated upto higher secondary followed by high school and middle school. The importance of formal and higher education for one's development in today's competitive world as realized by the parents might have induced them to send their children to schools and colleges. This finding is in accordance with the results obtained by Okwoche et al., (2015).

The result indicates that majority of the Krishak Mitra (84.16\%) were male. The result is in consonance with the findings of Oladele (2006).

The results indicated that majority of the respondents $(60.84 \%)$ had medium experience in present position. This might be due to that majority of selected farmers as Krishak Mitra 
were middle aged, thus their experience is also moderate. This finding is in line with the findings of Padmavathi (1996) and Praveen (2010).

The finding regarding land holding revealed that nearly half of the Krishak Mitra (45.84\%) were having medium size of land holding i.e. between 1 and 3 hectare. The probable reason might be due to fragmentation of farm families and increase in number of nuclear families. It is evident from the study that maximum Krishak Mitra (83.34\%) was having medium level of annual income. The possible reason may be that since majority of the respondents were having land between 1 and 3 ha. as indicated in the data. It is a proven fact that land is main source of income in agrarian society and large percent of Krishak Mitra have medium land holding. Hence more number of Krishak Mitra belonged to medium income groups. This finding is similar to the findings of Padmavathi (1996), Roy (2003) and Mishra (2005).

It was recorded in the study that most of the respondents $(68.33 \%)$ belonged to the category of medium mass media exposure. This might be due to the fact that mass media plays an important role in acquiring the latest information about agriculture and allied enterprises which are essential for Krishak Mitra in performing their job effectively in rural areas. This finding is also supported by Kumar and Sailaja (2012).

Majority of Krishak Mitra (72.50\%) came under medium level of extension agency contact. This might be due to the fact that Krishak Mitra were having medium level of contact with extension agency. Only those Krishak Mitra who were educated and rich might have subscribed to newspaper, farm magazine, books on agriculture and possessed television. This might be the reasons for medium extension contact of Krishak Mitra.
Further majority of Krishak Mitra belonged to middle age group. So, it is quite natural that their curiosity to participate in field visit and to visit exhibition would be low. This findingis in accordance with the findings of Kumar (1995), Padmavathi (1996), Chatterjee (2000), Kiran (2000), Praveen (2000), Roy (2003) and Nambiar (2013).

The results indicated that majority $(77.50 \%)$ of the respondents had medium level of information seeking behaviour. The medium information seeking behaviour might be attributed to medium mass media exposure and medium level of contact to the extension agency. The findings of the present study agree with the findings of Mishra (2005). Majority 54.17 per cent of the respondents had medium level of social participation. It can be concluded that the respondents had fairly good educational status. They either realized the importance of social participation or got opportunities of social participation.

Results indicated that majority of Krishak Mitra (60.82\%) had medium achievement motivation; this may be due to their medium social participation This finding is in agreement with that of Chatterjee (2000), Roy (2003), Mohan (2003), Babu (2005) and Mishra (2005).

\section{Role performance of Krishak Mitra}

In the present study, the role performance of Krishak Mitra was taken as dependent variable and was measured on the basis of performance of their job description. In the study role performance was operationalised as the degree in which Krishak Mitra carried out or actually performed their roles. Twenty seven roles of Krishak Mitras were finalized after consultation with the experts. The 27 roles as given in appendix was administered to Krishak MItra (respondents) who were asked to respond on three point continuum viz. 
maximum extent, to some extent and to minimum extent. A score of 3 for maximum extent, 2 for some extent and 1 for minimum extent was given. The possible score range was 27 to 81 . The 27 roles were summed up and the respondents were categorized into three categories based on mean and standard deviation viz. low, medium and high.

The data in Table 1 revealed the extent of role performance of Krishak Mitra. It can be inferred from the table that the roles performed by majority of the Krishak Mitra up to maximum extent were "inform about various government schemes for farmers benefit" (65.00\%), "provide information about agriculture technology to farmers and convincing them to adopt it" and "motivate farmers about the use of new technology in farming" each (60.83\%), "make planned visit to farmers' fields" and "assist in providing various services and input like seed, fertilizers, insecticide etc. in time" each $(60.00 \%)$, "provide special attention to study the needs and problems of small and marginal farmers" and "establish linkage between farmers and Agriculture Development Officers" each $(51.66 \%)$, "participate in meetings organised by agriculture development officers" $(50.00 \%)$, "gather information regarding personal details of farmers and their farm production" (48.33\%), "participate in village level meeting" (46.66\%), “develop implementation plan at village level for agriculture and related department" (42.50\%), "assist farmers in availing solution to technological issues in agriculture" (41.66\%) and "assistance in organizing demonstration, kisan gosthi and extension of researches at village level" (40.83\%).

It is also clear from the data that the roles as "organize farmers interest group" (60.83\%), "provide information about requirement of farmers regarding new technology in the monthly meeting" (54.16\%), “ensure implementation of cost cutting technologies in presence of farmers as per guidelines" $(52.50 \%)$, "ensure the dissemination of information through multi-media", "timely organization of farmers meetings and discussion to share information about different programmes", "maintain contact with local officials and organizations associated with Agriculture Department" and "carry out the demonstration on farmers field and keep records of demonstration" each (48.33\%), "maintain regular contact with RAEO and other officials of Agriculture Department regarding sharing of farmers problems and getting consultancy and guidance" (44.16\%), "assistance developing extension work plan at block level" (41.66\%) and "identify progressive farmers and local leaders and coordinate in adoption of technologies among other farmers through them" $(40.00 \%)$ were performed up to some extent by majority of Krishak Mitra.

Further, the data in Table 1 revealed that the roles like "maintaining input register to record the input needs and services required by farmers" $(62.50 \%)$, "attend regular training session organized by various department" and "assist in availing loan by farmers" each $(43.33 \%)$ and "maintaining record of work done and take follow up action as per instruction" (41.66\%), were performed to minimum extent by most of the Krishak Mitras.

An overall role performance of Krishak Mitra presented in Table 2 revealed that 58.34 per cent were in medium role performance category and nearly equal percentage i.e. 21.66 and 20.00 per cent belonged to high and low role performance category. Therefore, it may be concluded that majority of Krishak Mitra 58.34 per cent had medium level of role performance. 
Table.1 Profile of Krishak Mitra

\begin{tabular}{|c|c|c|c|c|}
\hline S. & \multicolumn{2}{|l|}{ Attributes } & \multirow{2}{*}{$\begin{array}{c}\text { Frequency } \\
22\end{array}$} & \multirow{2}{*}{$\begin{array}{c}\text { Percentage } \\
18.33\end{array}$} \\
\hline 1. & Age & Young (up to 30 year) & & \\
\hline & & Middle (31 to 45 years) & 81 & 67.50 \\
\hline & & old (above 45) & 17 & 14.17 \\
\hline \multirow[t]{7}{*}{2.} & \multirow[t]{7}{*}{ Education } & Illiterate & 0 & 0 \\
\hline & & Only read \& write & 0 & 0 \\
\hline & & Primary education & 0 & 0 \\
\hline & & Middle school & 13 & 10.83 \\
\hline & & High school & 37 & 30.83 \\
\hline & & Higher secondary & 51 & 42.50 \\
\hline & & Graduation/More & 19 & 15.84 \\
\hline \multirow[t]{2}{*}{3.} & Gender & Male & 101 & 84.16 \\
\hline & & Female & 19 & 15.84 \\
\hline \multirow[t]{3}{*}{4.} & \multirow{3}{*}{$\begin{array}{l}\text { Experience in } \\
\text { present position }\end{array}$} & Low (up to 4 year) & 29 & 24.16 \\
\hline & & Medium (5 to 12 years) & 73 & 60.84 \\
\hline & & High (Above 12 years) & 18 & 15.00 \\
\hline \multirow[t]{3}{*}{5.} & \multirow[t]{3}{*}{ Land holding } & Small (Up to 1 ha.) & 53 & 44.16 \\
\hline & & Medium (1.01 to 3 ha.) & 55 & 45.84 \\
\hline & & Large (Above 3.01 ha.) & 12 & 10.00 \\
\hline \multirow[t]{3}{*}{6.} & \multirow[t]{3}{*}{ Annual income } & Low (Up to Rs.10,000) & 0 & 0 \\
\hline & & Medium (Rs.10,001 to $1,90,000)$ & 100 & 83.34 \\
\hline & & High (Above Rs.1,90,001) & 20 & 16.66 \\
\hline \multirow[t]{3}{*}{7.} & \multirow{3}{*}{$\begin{array}{l}\text { Mass media } \\
\text { exposure }\end{array}$} & Low (upto 8 score) & 32 & 26.67 \\
\hline & & Medium (9 to 12 score) & 82 & 68.33 \\
\hline & & High (Above 12 score) & 6 & 5.00 \\
\hline \multirow[t]{3}{*}{8.} & \multirow{3}{*}{$\begin{array}{l}\text { Extension } \\
\text { agency } \\
\text { contact }\end{array}$} & Low (upto 23 score) & 25 & 20.83 \\
\hline & & Medium (24 to 31 score) & 87 & 72.50 \\
\hline & & High (Above 31 score) & 8 & 6.67 \\
\hline \multirow[t]{3}{*}{9.} & \multirow{3}{*}{$\begin{array}{l}\text { Information } \\
\text { seeking } \\
\text { behaviour }\end{array}$} & Low (16 to 34 score) & 20 & 16.66 \\
\hline & & Medium (35 to 44 score) & 93 & 77.50 \\
\hline & & High (Above 44 score) & 7 & 5.84 \\
\hline \multirow[t]{3}{*}{10.} & \multirow{3}{*}{$\begin{array}{l}\text { Social } \\
\text { participation }\end{array}$} & Low (Up to 10 score) & 31 & 25.83 \\
\hline & & Medium (11 to 14 score) & 65 & 54.17 \\
\hline & & High (Above 14 score) & 24 & 20.00 \\
\hline \multirow[t]{3}{*}{11.} & \multirow{3}{*}{$\begin{array}{l}\text { Achievement } \\
\text { motivation }\end{array}$} & Low (21 to 45 score) & 22 & 18.34 \\
\hline & & Medium (46 to 55 score) & 73 & 60.82 \\
\hline & & High (Above 55 score) & 25 & 20.84 \\
\hline
\end{tabular}


Table.2 Extent of role performance of Krishak Mitra

\begin{tabular}{|c|c|c|c|c|}
\hline \multirow{2}{*}{$\begin{array}{l}\text { S. } \\
\text { No. }\end{array}$} & \multirow[t]{2}{*}{ Role performance } & \multicolumn{3}{|c|}{ Response categories } \\
\hline & & $\begin{array}{l}\text { Maximum } \\
\text { Extent }\end{array}$ & $\begin{array}{c}\text { To some } \\
\text { extent }\end{array}$ & $\begin{array}{l}\text { Minimum } \\
\text { extent }\end{array}$ \\
\hline 1. & Make a planned visit to farmers' fields & $\begin{array}{l}72 \\
(60)\end{array}$ & $\begin{array}{c}48 \\
(40)\end{array}$ & $\begin{array}{c}0 \\
(0)\end{array}$ \\
\hline 2. & Organize farmer interest group & $\begin{array}{c}34 \\
(28.33)\end{array}$ & $\begin{array}{c}73 \\
(60.83)\end{array}$ & $\begin{array}{c}13 \\
(10.84)\end{array}$ \\
\hline 3. & $\begin{array}{l}\text { Assistance in organizing demonstration, kisan gosthi and extension of } \\
\text { researches at village level }\end{array}$ & $\begin{array}{c}49 \\
(40.83)\end{array}$ & $\begin{array}{c}42 \\
(35)\end{array}$ & $\begin{array}{c}29 \\
(24.17)\end{array}$ \\
\hline 4. & Assistance in developing extension work plan at block level & $\begin{array}{c}45 \\
(37.50)\end{array}$ & $\begin{array}{c}50 \\
(41.66)\end{array}$ & $\begin{array}{c}25 \\
(20.84)\end{array}$ \\
\hline 5. & $\begin{array}{l}\text { Develop implementation plan at village level for agriculture and related } \\
\text { department }\end{array}$ & $\begin{array}{c}51 \\
(42.50)\end{array}$ & $\begin{array}{c}48 \\
(40)\end{array}$ & $\begin{array}{c}21 \\
(17.50)\end{array}$ \\
\hline 6. & Participate in village level meeting & $\begin{array}{c}56 \\
(46.66)\end{array}$ & $\begin{array}{c}50 \\
(41.66)\end{array}$ & $\begin{array}{c}14 \\
(11.68)\end{array}$ \\
\hline 7. & Ensure the dissemination of information through multi-media & $\begin{array}{c}28 \\
(23.33)\end{array}$ & $\begin{array}{c}58 \\
(48.33)\end{array}$ & $\begin{array}{c}34 \\
(28.34)\end{array}$ \\
\hline 8. & $\begin{array}{l}\text { Provide information about agriculture technology to farmers and } \\
\text { convincing them to adopt it }\end{array}$ & $\begin{array}{c}73 \\
(60.83)\end{array}$ & $\begin{array}{c}28 \\
(23.34)\end{array}$ & $\begin{array}{c}19 \\
(15.83)\end{array}$ \\
\hline 9. & $\begin{array}{l}\text { Gather information regarding personal details of farmers and their farm } \\
\text { production }\end{array}$ & $\begin{array}{c}58 \\
(48.33)\end{array}$ & $\begin{array}{c}32 \\
(26.67)\end{array}$ & $\begin{array}{c}30 \\
(25)\end{array}$ \\
\hline 10. & Maintain record of work done and take follow up action as per instruction & $\begin{array}{c}44 \\
(36.66)\end{array}$ & $\begin{array}{c}26 \\
(21.68) \\
\end{array}$ & $\begin{array}{c}50 \\
(41.66)\end{array}$ \\
\hline 11. & $\begin{array}{l}\text { Maintain input register to record the input needs and services required by } \\
\text { farmers }\end{array}$ & $\begin{array}{c}25 \\
(20.84)\end{array}$ & $\begin{array}{c}20 \\
(16.66)\end{array}$ & $\begin{array}{c}75 \\
(62.50)\end{array}$ \\
\hline 12. & Attend regular training session organised by various departments & $\begin{array}{c}28 \\
(23.34)\end{array}$ & $\begin{array}{c}40 \\
(33.33)\end{array}$ & $\begin{array}{c}52 \\
(43.33)\end{array}$ \\
\hline 13. & Participate in meetings organised by Agriculture development officers & $\begin{array}{c}60 \\
(50)\end{array}$ & $\begin{array}{c}32 \\
(26.66)\end{array}$ & $\begin{array}{c}28 \\
(23.34)\end{array}$ \\
\hline 14. & $\begin{array}{l}\text { Provide information about requirement of farmers regarding new } \\
\text { technology in the monthly meeting }\end{array}$ & $\begin{array}{c}32 \\
(26.66)\end{array}$ & $\begin{array}{c}65 \\
(54.16)\end{array}$ & $\begin{array}{c}23 \\
(19.18)\end{array}$ \\
\hline 15. & Assist farmers in availing solution to technological issues in agriculture & $\begin{array}{c}50 \\
(41.66)\end{array}$ & $\begin{array}{c}48 \\
(40)\end{array}$ & $\begin{array}{c}22 \\
(18.34)\end{array}$ \\
\hline 16. & $\begin{array}{l}\text { Identify progressive farmers and local leaders and coordinate in adoption of } \\
\text { technologies among other farmers through them }\end{array}$ & $\begin{array}{c}37 \\
(30.84)\end{array}$ & $\begin{array}{c}48 \\
(40)\end{array}$ & $\begin{array}{c}35 \\
(29.16)\end{array}$ \\
\hline 17. & $\begin{array}{l}\text { Timely organization of farmers meetings and discussion to share } \\
\text { information about different programmes }\end{array}$ & $\begin{array}{c}44 \\
(36.67)\end{array}$ & $\begin{array}{c}58 \\
(48.33)\end{array}$ & $\begin{array}{c}18 \\
(15)\end{array}$ \\
\hline 18. & $\begin{array}{l}\text { Provide special attention to study the needs and problems of small and } \\
\text { marginal farmers }\end{array}$ & $\begin{array}{c}62 \\
(51.66)\end{array}$ & $\begin{array}{c}36 \\
(30)\end{array}$ & $\begin{array}{c}22 \\
(18.34)\end{array}$ \\
\hline 19. & $\begin{array}{l}\text { Maintain regular contact with RAEO and other officials of Ag. Department } \\
\text { regarding sharing of farmers problems and getting consultancy and } \\
\text { guidance }\end{array}$ & $\begin{array}{c}49 \\
(40.84)\end{array}$ & $\begin{array}{c}53 \\
(44.16)\end{array}$ & $\begin{array}{l}18 \\
(15)\end{array}$ \\
\hline 20. & $\begin{array}{l}\text { Maintain contacts with local officials and organizations associated with } \\
\text { agriculture department }\end{array}$ & $\begin{array}{c}47 \\
(39.17)\end{array}$ & $\begin{array}{c}58 \\
(48.33)\end{array}$ & $\begin{array}{c}15 \\
(12.50)\end{array}$ \\
\hline 21. & $\begin{array}{l}\text { Assist in providing various services and inputs like seed, fertilizers, } \\
\text { insecticide etc. in time }\end{array}$ & $\begin{array}{c}72 \\
(60)\end{array}$ & $\begin{array}{c}32 \\
(26.66)\end{array}$ & $\begin{array}{c}16 \\
(13.34)\end{array}$ \\
\hline 22. & Assist in availing loan by farmers & $\begin{array}{c}45 \\
(37.50)\end{array}$ & $\begin{array}{c}23 \\
(19.17)\end{array}$ & $\begin{array}{c}52 \\
(43.33)\end{array}$ \\
\hline 23. & $\begin{array}{l}\text { Carry out the demonstration on farmers field and keep records of } \\
\text { demonstration }\end{array}$ & $\begin{array}{c}26 \\
(21.67)\end{array}$ & $\begin{array}{c}58 \\
(48.33)\end{array}$ & $\begin{array}{l}36 \\
(30)\end{array}$ \\
\hline 24. & $\begin{array}{l}\text { Ensure implementation of cost cutting technologies in presence of farmers } \\
\text { as per guideline }\end{array}$ & $\begin{array}{c}42 \\
(35)\end{array}$ & $\begin{array}{c}63 \\
(52.50)\end{array}$ & $\begin{array}{c}15 \\
(12.50)\end{array}$ \\
\hline 25. & Inform about various government schemes for farmers benefit & $\begin{array}{l}78 \\
(65)\end{array}$ & $\begin{array}{c}30 \\
(25)\end{array}$ & $\begin{array}{c}12 \\
(10)\end{array}$ \\
\hline 26. & Motivate farmers about the use of new technology in farming & $\begin{array}{c}73 \\
(60.83)\end{array}$ & $\begin{array}{c}32 \\
(26.67)\end{array}$ & $\begin{array}{c}15 \\
(12.50)\end{array}$ \\
\hline 27. & Establish linkage between farmers and Agriculture Development Officers & $\begin{array}{c}62 \\
(51.66)\end{array}$ & $\begin{array}{c}38 \\
(31.66)\end{array}$ & $\begin{array}{c}20 \\
(16.68)\end{array}$ \\
\hline
\end{tabular}


This might be due to the fact that most of the Krishak Mitra had medium level of medium level of achievement motivation. The other reasons that can be attributed for this trend might be working environment, encouragement, cooperation of extension functionaries and related departments and availability of services etc. The finding of the present study is in line with the studies conducted by Kumar (1995), Padmavathi (1996), Praveen (2000), Mohan (2000) and Mishra (2005).

\section{Relationship of profile of Krishak Mitra with their role performance}

It could be seen from Table 1, that variables namely experience in present position, mass media exposure, information seeking behaviour and social participation were significant and positively correlated with role performance of Krishak Mitra while remaining seven variables namely age, education, gender, land holding, annual income, extension agency contact and achievement motivation were found to be non-significant. The null hypothesis was therefore, accepted with respect to seven variables i.e. age, education, gender, land holding, annual income, extension agency contact and achievement motivation.

\section{Constraints faced by Krishak Mitra in role performance}

It is evident from the data that main problems faced by the Krishak Mitra was low payment $(87.50 \%)$ followed by lack of literacy and technical knowledge of farmers (80.83\%), unavailability of latest technical literature $(77.50 \%)$, lack of awareness and traditional attitude of farmers $(65.83 \%)$, problem of mobility $(52.50 \%)$, lack of guidance by concerned staff $(50.83 \%)$, unavailability of contact farmers as per schedule $(47.50 \%)$, and local leader pressure $(30.00 \%)$.
In conclusion, the findings regarding role performance of Krishak Mitra revealed that majority of the respondents were having medium level of role performance. It was also found that role performance was affected by the experience, mass media exposure, information seeking behaviour and social participation of Krishak Mitras. Regarding the constraints faced by Krishak Mitra in role performance, low payment towards performance of their role was the main problems responded by the Krishak Mitra. An understanding of the factors and constraints faced by Krishak Mitra in discharging their roles may serve as a feedback to the planers, extension personnel, scientist and development agencies while implementation of any scheme.

\section{References}

Babu DV. 2005. Job competence of Agricultural Officers in the State Department of Agriculture in TamilNadu. M.Sc. (Ag.) Thesis, A. N.G.R.A.U., Hyderabad.

Chatterjee RK. 2000. A study on the impact of National Watershed Development Project for Rainfed Areas (NWDPRA) in Burdwan district of West Bengal. M.Sc. (Ag.) Thesis, A.N.G.R.A.U., Hyderabad.

Cooper AW and Graham DL. 2001. Competencies needed to be successful county agents and county superiors. J. Exten. 39: 1-8. Retrieved from http://www.joe.org/joe/2001february/rb 3.php

Gibson JD and Hillison J. 1994. Training needs of area specialized extension agents. J. Exten. 32: 1-5. Retrieved from http://www.joe.org/joe/1994october/a3. html

Kiran SN. 2000. A study on the participation of farm women in agriculture and allied activities in Chittoor district of Andhra 
Pradesh. M.Sc. (Ag.) Thesis, A.N.G.R.A.U., Hyderabad.

Kumar NK and Sailaja. 2012. A study on personal traits of model farmers in technology dissemination. International Journal of Farm Sciences 2(2): 149-154.

Martiz D. 1995. Leadership and mobilizing potential, Human Resource Management. International Journal of Global Business. 10(1): 8-16.

Miller RL and Cox L. 2006. Technology transfer preferences of researchers and producers in sustainable agriculture. J. Exten. 44: 1-6.

Mishra D. 2005.A comparative study on the job performance, job satisfaction and constraints of men and women extension officers of Karnataka State Department of Agriculture. M.Sc. (Ag.) U.A.S., Dharwad.

Mohan B. 2000. A study on job performance and job satisfaction of Assistant Agricultural Officers in Northern districts of Karnataka. M.Sc. (Ag.) Thesis, U.A.S., Dharwad.

Nambiar N. 2013. A study on job performance of Rural Agriculture Extension Officers in Jabalpur district of Madhya Pradesh. M.Sc. (Ag.) Thesis, J.N.K.V.V. Jabalpur.

Okwoche VAO, Eziehe JC and Agabi V. 2015. Determinants of job satisfaction among extension agents in Benue State Agricultural and Rural Development Authority (Bnarda), Benue state,
Nigeria. European Journal of Physical and Agricultural Sciences 3(2): 38-48.

Oladele OI. 2006. Influence of personal characteristics on job performance among extension agents and agricultural researchers in South Western Nigeria. Agricultural and Food Science Journal of Ghana 6: 431-443.

Padmavathi M. 1996. Role perception and role performance of MitraKisans in National Watershed Development Project for Rainfed Area (NWDPRA) in Chittoor district of Andhra Pradesh. M.Sc. (Ag.) Thesis, A.N.G.R.A.U., Hyderabad.

Praveen D. 1997.A study on role perception and role performance of MitraKisans in transfer of watershed technology in Ranga Reddy district of Andhra Pradesh. M.Sc. (Ag.) Thesis, A.N.G.R.A.U., Hyderabad.

Rao ST. 2002. Organizational climate and job performance of Horticultural Officers of the State Department of Horticulture (A.P.) M.Sc. (Ag.) Thesis, A.N.G.R.A.U., Hyderabad.

Roy SK. 2003. Role perception and role performance of Mitra Kisans in National Watershed Development Project for Rainfed Areas (NWDPRA) in Andaman district of Union Territory of Andaman and Nicobar Island. M.Sc. (Ag.) Thesis, A.N.G.R.A.U., Hyderabad.

\section{How to cite this article:}

Veerpal Maina, Kamini Bisht, S.P. Singh and Sheela Raghuwanshi. 2019. Role Performance of Krishak Mitra. Int.J.Curr.Microbiol.App.Sci. 8(01): 747-754. doi: https://doi.org/10.20546/ijcmas.2019.801.082 